\author{
ПОРІВНЯЛЬНА ХАРАКТЕРИСТИКА \\ РЕГІОНАЛЬНОГО РОЗВИТКУ ІНКЛЮЗИВНОГО ТУРИЗМУ \\ В ПРИЧОРНОМОР'Ï ТА ІСПАНСЬКІЙ КАТАЛОНІї \\ COMPARATIVE CHARACTERISTICS \\ OF THE REGIONAL DEVELOPMENT OF INCLUSIVE TOURISM \\ IN THE BLACK SEA REGION AND SPANISH CATALONIA
}

УДК 339.166.5:658.825

https://doi.org/10.32843/bses.68-9

\section{Бєлоусова Н.В.}

к.геогр.н., доцент,

доцент кафедри аерокосмічної геодезії та землеустрою

Національний авіаційний університет

\section{Bielousova Natalia}

National Aviation University

\begin{abstract}
У статті розкривається сутність інклюзивного туризму як нового напряму туристичної сорери, для впровадження якого в регіони України, потрібно досконало вивчити світовий досвід, зіставити реальні можливості природно-ресурсного й туристсько-рекреаційного потенціалу, а також рівень розвитку галузевої інфрраструктури регіону, яка дотична до процесу реалізаціі програми з розвитку інклюзивного туризму. В якості прикладу європейського досвіду щодо створення інклюзивного середовища, був розглянутий регіон Іспанської Каталонії, який має схожі риси з Причорноморським регіоном України: кліматичні та природні ресурси, наявність берегової лінії з пляжами для відпочинку та різноманітного дозвілля, широкий спектр туристичних послуг і пропозицій для всіх туристів, в тому числі для людей з інклюзією та осіб з інвалідністю. Наданий прогноз стратегії впровадження інклюзивного туризму в Причорноморському регіоні України.

Ключові слова: інклюзивний туризм, туристичні послуги, інклюзивне середовище, Причорноморський регіон, Іспанська Каталонія.
\end{abstract}

B статье раскрывается сущность инклюзивного туризма как нового направ- ления туристической сфреры, для внедрения которого в регионы Украины, нужно досконально изучить мировой опыт, сопоставить реальные возможности природно-ресурсного и туристско-рекреационного потенциала, а также уровень развития отраслевой инсрраструктуры региона, которая касательная к процессу реализации программы по развитию инклюзивного туризма. В качестве примера европейского опыта по созданию инклюзивного среды, был рассмотрен регион Испанской Каталонии, который имеет схожие черты с Причерноморским регионом Украины: по климатическим и природным ресурсам, наличию морской береговой линии с пляжами для отдыха и разнообразного досуга, широким спектром туристических услуг и предложений для всех туристов, в том числе для людей с инклюзией и лиц с инвалидностью. Предоставлен прогноз стратегии внедрения инклюзивного туризма в Причерноморском регионе Украины.

Ключевые слова: инклюзивный туризм, туристические услуги, инклюзивное среду, Причерноморский регион, Испанский Каталония.

The article reveals the essence of inclusive tourism as a new direction of the tourism sector, for the introduction of which in the regions of Ukraine, it is necessary to thoroughly study the world experience, compare the real possibilities of the natural resource and tourist and recreational potential, as well as the level of development of the sectoral infrastructure of the region, which is related to the implementation process. programs for the development of inclusive tourism. As an example of European experience in creating an inclusive environment, the region of Spanish Catalonia was considered, which has similar features to the Black Sea region of Ukraine: climatic and natural resources, the presence of a coastline with beaches for recreation and a variety of leisure activities, a wide range of tourist services and offers for all tourists, including for people with inclusion and people with disabilities. Provides a comprehensive description of the inclusive environment of the city of Barcelona - the center of Catalonia, which is considered the most suitable for tourists with inclusion (people with disabilities): transport infrastructure, information centers for the provision of various services and information, accessible Internet sites, availability of special transport, adapted hotel rooms and points food, availability of tourist locations, etc.). The attention is focused on Catalonia, as a region where there is already an established mechanism for providing tourist services to inclusive tourists, but as a rule to people with disabilities. Therefore, the question arises of involving all categories of inclusive tourists, including representatives of socially vulnerable segments of the population, including pensioners. This will make it possible to equalize the rights of all citizens to rest and receive social and cultural benefits. From the point of view of economic efficiency, the process of increasing the number of tourists will be natural. This step will expand the range of travel services, increase the number of jobs and solve the problem of socializing people with inclusion. The general characteristics of the resource and infrastructural component of the Black Sea region made it possible to assess the region's capabilities, identify problems and predict the strategy of introducing inclusive tourism in the future in this region of Ukraine. Key words: inclusive tourism, tourist senvices, inclusive environment, Black Sea region, Spanish Catalonia.

Постановка проблеми. Протягом останніх десятиліть туризм став однією з найбільш перспективних та прогресивних галузей світової економіки, яка входить у трійку найбільш дохідних сорер отримуваних прибутків. Туризм сприяє зміцненню політичних, економічних, соціальних і культурних зв'язків між країнами світу, що дає можливість познайомитись 3 кращими світовими практиками в галузі туристичного обслуговування та дослідити функціональні можливості розвитку туризму в різних регіонах світу, де, окрім класичних туристичних напрямів, пропонується туристичне обслуговування інклюзивних туристів (людей з інвалідністю, пенсіонерів, осіб з надмірною вагою та ін.). 
Для надання туристичних послуг даній групі туристів, потрібно мати не тільки природно-ресурсний та туристсько-рекреаційний потенціал, але й сорормовану матеріально-технічну базу, яка б відповідала вимогам щодо обслуговування людей з інклюзією (архітектурна доступність, пристосованість туристичних локацій, готелів, ресторанів, наявність спецтранспорту, пропозиції адаптованих маршрутів туристичними агенціями тощо). Така практика вже існує в Україні в Черкаській області, яка виступила ініціатором розробки та впровадження інклюзивного туризму в систему соціальної реабілітації людей з інклюзією. Враховуючи загально національну програму з подальшого впровадження інклюзивного туризму в регіони України, доцільно розглянути Причорноморський регіон, який за природно-ресурсним і туристсько-рекреаційним потенціалом доволі схожий с регіоном іспанської Каталонії, яка вже має створене інклюзивне середовище та досвід туристичного обслуговування інклюзивних туристів. Тому логічним $€$ вивчення досвіду Іспанії для визначення пріоритетності розвитку та впровадження інклюзивного туризму на прикладі Причорноморського регіону, який може стати привабливою територією для туристичного відпочинку та оздоровлення людей $з$ інклюзією й зміцнення макроекономічних показників розвитку України.

Аналіз останніх досліджень і публікацій. Питанням регіонального розвитку туристичної галузі присвячені наукові роботи багатьох вітчизняних учених різних спеціальностей, таких як: М. Борущак, Т. Галушкіна, Б. Данилишин, Л. Ковальська, О. Любіцева, Л. Мельник, В. Руденко, Т. Ткаченко та ін. Регіональний розвиток лікувально-оздоровчого туризму, зонування й планування територій країни та регіонів досліджували такі вчені, як: Ю. Білоконь, А. Іванов, В. Олійник. Проблематикою туристичного розвитку Причорноморського регіону займаються В. Петранівський, Н. Фоменко, Б. Буркинський [11] та інші. Проте в умовах динамічного розвитку зовнішнього середовища проблеми дослідження тенденцій розвитку інклюзивного туризму потребують подальших досліджень.

Постановка завдання. Метою статті $€$ визначення тенденцій розвитку інклюзивного туризму Причорноморського регіону України та Іспанської Каталонії, з метою створення сучасного туристичного продукту для людей з інклюзією, конкурентоспроможного на міжнародному ринку.

Виклад основного матеріалу дослідження. Індустрія туризму вважається одним з перспективних секторів, що визначає рівень доходу світової економіки. Навіть в умовах пандемії COVID-19, в світовій індустрії туризму зберігається позитивна тенденція до зростання туристичної активності.

В останні роки все частіше мова ведеться про розширення спектру надання туристичних послуг і залучення до туристичної діяльності ті верстви населення, які довгий час залишались поза уваги світової спільноти. Мається на увазі категорії людей 3 інклюзією, які за фрізичними, психічними чи фрізіологічними показниками не можуть самостійно здійснювати туристичні подорожі (або навіть із супроводом). В першу чергу до категорії інклюзивних туристів відносять людей 3 інвалідністю (різних нозологій), соціально мало захищених осіб (категорії людей, що потребують соціальної допомоги з різних причин, в тому числі пенсіонери), людей 3 надмірною вагою та інших людей з інклюзією, для яких існування та переміщення у сучасному соціумі не завжди $є$ коморортним, а для окремих категорій осіб з інвалідністю - не можливим. Тому постає питання створення інклюзивного середовища, яке дозволить людям 3 інклюзією користуватись послугами туристичної сорери та почувати себе повноцінними громадянами суспільства.

У зв'язку з тими, що проблеми отримання туристичних послуг починають виникати ще на стадії планування подорожей, Україні, як країні, що поступово інтегрується в європейський простір, корисно вивчити, дослідити та перейняти закордонний досвід щодо впровадження інклюзивного туризму, зокрема в Європі, Ізраїлі, США, де створені спеціальні сайти, наприклад для людей з інвалідністю, для зручного вибору та визначення доступності історичних пам'яток, об'єктів та міст, музеїв та виставок, готелів і ресторацій, локацій для відпочинку (паркові або зелені зони), аквапарків та інших атракцій, з вказівкою агенцій, в яких можна замовити спецтранспорт або скористатись інфрормацією про адаптований міський транспорт для людей з інвалідністю.

В межах європейського простору найбільш пристосованим інклюзивним середовищем вважається регіон іспанської Каталонії з центром містом Барселона. Метою створення доступного середовища в Барселоні стало бажання досягти згуртованого міста, яке сприятиме якості життя та повазі до різноманітності. Влада міста та жителі роблять все можливе для того щоб полегшити доступ до найбільш проблемних пунктів, громадського транспорту та зробити місто доступним для людей 3 інвалідністю. Тому, даний регіон характеризується розвиненою інтернет-мережею сайтів для інклюзивних туристів, яка дозволяє ознайомитись 3 переліком історичних та культурних пам'яток, доступних для людей 3 інвалідністю, дізнатися подробиці функціонування транспорту, знайти готель 3 доступною інфрраструктурою та скористатись послугами спеціалізованих сервісів, замовити тур за певним туристичним маршрутом, познайомитись 3 відеоматеріалом, який адаптований для людей з порушенням слуху, адже дублюється жестовою мовою [3]. 
Спеціально створене туристичне агентство Barcelona Special Traveller [5] спеціалізується на туристичних послугах для інклюзивних туристів, враховуючи всі потреби своїх клієнтів та пропонуючи персоналізовані поїздки (досвід створення повністю інклюзивної екскурсії Easy Walking Tour Gòtic, адаптований до потреб маломобільних груп) [9], які гарантують доступність перевезень, проживання та всі необхідні супутні послуги (тури, екскурсії, різноманітне дозвілля тощо) [4]. Даний проект виконує головне завдання сучасного суспільства - створення рівних можливостей для всіх під час подорожей, на базі практичного досвіду, глибокого знання потреб туриста з інвалідністю та з урахуванням їх побажань [1].

Інклюзивний туризм став однією 3 головних цілей Каталонського агентства з туризму (Agencia Catalana de Turisme [7]), що пропонує понад 1100 туристичних об'єктів, які адаптовані для людей з інвалідністю, готелі, транспорт та заклади харчування, які пристосовані для осіб з інвалідністю та має свій інфрормаційний сайт.

Каталонія має понад 150 км високоякісних доріг, які проходять в межах зелених зон регіону, десятки доступних стежок і численні пляжі на узбережжі Каталонії, які є доступними та мають все необхідне для обслуговування людей з інклюзією [8]. В рамках туристичного дозвілля пропонуються послуги 3 польотів на адаптованих повітряних кулях, відвідування вітрильних гуртків, а також активні види відпочинку: катання на байдарках, дайвінг, сплави річкою, верхова їзда тощо [13]. Адаптована під інклюзивного туриста інтернет-мережа з необхідною інформацією щодо бронювання екскурсій, готелів та формування транспортної карти [12].

Гірськолижний курорт La Molina адаптував для людей з інклюзією споруди та деякі свої траси для катання на лижах. Національний художній музеї Каталонії вперше в Іспанії запропонував людям з вадами слуху екскурсію за допомогою жестової мови (каталонською та іспанською) та міжнародною системою знаків (SIS) [10].

Не зважаючи на те, що Каталонія стала передовим містом в питаннях практичного впровадження інклюзивного туризму, протягом останніх років вирішувались питання над усуненням архітектурних та комунікаційних бар'єрів. Окрім того, акцент, в наданні туристичних послуг, робився на людях 3 інвалідністю. Але, згідно Міжнародних документів про створення інклюзивного середовища, безбар'єрність, допомогу мало мобільним групам людей [2], до інклюзивних туристів відносять й інші категорії людей, які теж потребують уваги і комфортного сервісу. Тому, для створення інклюзивного середовища в Україні необхідно враховувати не тільки світовий досвід, але й національні інтереси, менталітет народу, особливості ресурсної бази, рівень розвитку галузевої інфрраструктури, а також вираховувати дохідну частину даного проекту, яка є запорукою економічної стабільності країни. Причорномор'я для України, як і Каталонія для Іспанії, одна з найбільш привабливих територій для розвитку туризму, рекреації, цікавого відпочинку та різноманітних дозвіллєвих програм. Маючи сприятливо-коморортні кліматичні умови, наявність морської акваторії і прибережну смугу пляжів, розгалужену туристичну інфрраструктуру та сучасну транспортну мережу, Причорномор'я має всі шанси конкурувати з курортами Європи та світу.

Наприклад, з метою створення умов для розвитку належної інклюзивної інфраструктури на території Херсонської області, необхідно долучити представників місцевих громад, органів виконавчої влади, туристичних підприємств, громадських об'єднань, бізнес-асоціацій, адміністрації об'єктів природно-заповідного фронду, комунальних установ, та інших установ і підприємств, дотичних до сорери надання туристичних послуг. Окрім того, продовжувати проектну діяльність щодо адаптації туристичних дестинацій під потреби людей з інклюзією (транспорт, зупинки, готелі, заклади відпочинку та оздоровлення, ресторани, пляжі, музеї, візитцентри національних природних парків та біосорерних заповідників, вбиральні, та інші об'єкти).

Пляжні території мають бути облаштовані: пандусами з поручнями, під”іздами, пляжними дерев'яними доріжками з тросом, колясками-амсібіями, пляжними кабінками (роздягальнями) 3 лавками, пляжними алюмінієвими парасолями та шезлонгами на колесах, ігровими комплексами для дітей 3 інвалідністю, модульними вбиральнями із спеціальним устаткуванням та інвентарем. Готельні заклади мають мати в наявності спеціалізований номерний фонд для людей з особливими потребами (облаштування при будівництві, реконструкції, проведенні модернізації матеріально-технічної бази).

Також, при створенні інклюзивного простору необхідним є облаштування: спеціальними направляючими доріжками 3 тактильної плитки для людей з вадами зору, звуковими маячками перед входом до музеїв, обладнанням для внутрішнього та зовнішнього озвучення зупинок у громадському транспорті, спеціальними місцями для паркування транспортних засобів, які належать особам 3 інвалідністю, належним оснащенням зупинок громадського транспорту, інформаційновказівними знаками, візуальним і світловим сповіщенням, освітленням та оснащенням 3 «кнопками викликів». Широко має використовуватись шриот Брайля та послуги перекладачів жестової мови та багато інших аспектів [6].

Окрім Херсонської області, такі ж проблеми притаманні Одеській і Миколаївській областям, в яких, наряду з низьким рівнем облаштованості об'єктів для інклюзивних туристів, існує проблема 
обізнаності працівників сорери гостинності щодо якісного обслуговування подорожуючих 3 обмеженими можливостями, особливо туристів з інших країн (низький рівень знань іноземних мов, обізнаності щодо традицій тієї чи іншої країни та їх гастрономічних уподобань, невідповідність ціни та якості наданих послуг).

Для одержання позитивного результату з впровадження інклюзивного туризму в Причорноморському регіоні, i, як наслідок, збільшення кількості туристів, необхідно:

- визначити пріоритети регіону щодо створення інклюзивного середовища;

- розпочати різнобічну інфрормаційно-роз'яснювальну роботу серед працівників сорери туризму й дотичних до неї підприємств і організацій;

- проводити навчальні тренінги, семінари майстер-класи для персоналу та працівників туристичних агенцій, ресторацій та готельного бізнесу;

- залучати до даного процесу органи місцевого самоврядування у взаємодії 3 підприємствами, установами та організаціями області.

\section{Висновки з проведеного дослідження.}

1. Світовий досвід показує, що туристи з інклюзією, і пв першу чергу з інвалідністю, потребують створення комфрортного інклюзивного середовища, яке б задовольняло усі людські потреби, при цьому займаючи важливе місце в сорері туризму. Практика упровадження інклюзивного туризму закордоном доводить, що створення безбар'єрного середовища, адаптація екскурсійних маршрутів, туристичних та історичних пам'яток до потреб осіб з інвалідністю є доступним завданням для практичного вирішення. Прикладом є Каталонія як туристичний регіон Іспанії.

2. Україна має приклади розвитку та впровадження інклюзивного туризму в різних країнах світу щодо організації надання туристичних послуг особам 3 інклюзією, зокрема створення спеціальних сайтів, брошур, додатків для смарторонів, адаптація екскурсійних маршрутів, архітектурних та історичних пам'яток для осіб з інвалідністю.

3. Причорноморський регіон, як територія 3 різноманітними природними, туристсько-рекреаційними, історико-культурними ресурсами та розвиненою інфрраструктурою, перспективна для створення інклюзивного середовища, яке буде сприяти реабілітації та соціалізації людей 3 інклюзією.

4. Спеціальна підготовка працівників туристичної галузі, які працюють та надають послуги особам 3 інклюзією, адаптація сайтів туристичних кампаній для осіб з порушеннями зору та слуху, вибудовування стратегії розвитку інклюзивного туризму з залученням органів самоврядування, дозволить планомірно розпочати процес впровадження інклюзивного туризму в даному регіоні та створити базис економічного зростання.

\section{БІБЛІОГРАФІЧНИЙ СПИСОК:}

1. About us Barcelona Special Traveler. URL: https://www.barcelonaspecialtraveler.com/aboutHus (дата звернення: 26.06.2021).

2. Анализ зарубежного опыта развития внутреннего и въездного туризма. URL: http://council.gov.ru/ media/files/m7qn478mzUhopFipLvNYSt66AAENHQZJ.pdf (дата звернення: 26.06.2021).

3. Barcelona.Accessible.URL:https://www.barcelonaturisme.com/wv3/es/page/47/barcelonaHaccesible.html (дата звернення: 26.06.2021).

4. Barcelona. Special traveler. URL: https://siidon. guttmann.com/es/recurso/barcelonaHspecialHtraveler (дата звернення: 26.06.2021).

5. Barcelona. Special traveler. URL: https://www.barcelonaspecialtraveler.com (дата звернення: 26.06.2021).

6. Дикань О.В., Глушенко Т.М. Тенденції розвитку ринку туристично-рекреаційних послуг, потенційно застосовні у Причорноморському регіоні. Причорноморські економічні студії. 2018. Вип. 32. C. 111-115.

7. Catalan Tourist Board. URL: http://act.gencat.cat (дата звернення: 18.06.2021).

8. Cataluña apuesta por el turismo accesible. URL: https://cronicaglobal.elespanol.com/vida/cataluna HturismoHaccesible_158339_102.html (дата звернення: 16.06.2021).

9. Easy walking tour gòtic. URL: https://bcnshop. barcelonaturisme.com/shopv3/en/product/23941/easy HwalkingHtourHgotic.html (дата звернення: 16.06.2021).

10. Top 10 tips on inclusive tourism. URL: https://www.visitbritain.org/sites/default/files/vbH corporate/top_10_tips_inclusive_tourism.pdf (дата звернення: 18.06.2021).

11. Соціально-економічний розвиток регіонів Українського Причорномор'я: теорія, методологія, практика : монограсрія / Б.В. Буркинський, В.М. Осипов, О.В. Моліна, В.Ф. Горячук, І.Д. Півоварчук; Ін-т пробл. ринку та екон.-екол. дослідж. НАН України, 2010. 374 c.

12. Tourism for All. URL: https://www.tourismforall.co.uk (дата звернення 16.06.2021).

13. Turismo accesible. URL: http://act.gencat.cat/ 408/turismoHaccesible/?lang=es (дата звернення 16.06.2021).

\section{REFERENCES:}

1. About US Barcelona Special Traveler. Available at: https://www.barcelonaspecialtraveler.com/aboutHus (accessed 26 June 2021).

2. Analiz zarubezhnogo opyta razvitiya vnutrennego i vezdnogo turizma [Analysis of foreign experience of development of internal and entrance tourism]. Analitical bulletin. URL: http://council.gov.ru/media/files/m7qn478mzUhopFipLvNYSt66AAENHQZJ.pdf (accessed 26 June 2021).

3. Barcelona. Accessible. Available at: https://www.barcelonaturisme.com/wv3/es/page/47/barcelonaHaccesible.html (accessed 26 June 2021).

4. Barcelona. Special Traveler. Available at: https://siidon.guttmann.com/es/recurso/barcelonaHspecialHtraveler (accessed 26 June 2021). 
5. Barcelona. Special Traveler. Available at: https://www.barcelonaspecialtraveler.com (accessed 26 June 2021).

6. Dikan A.V., Glushenko T.M. (2018) Tendentsii razvitiya rynka turistsko-rekreatsionnykh uslug potentsial'no primenimy v Chernomorskom regione. Razvitiye proizvoditel'nykh sil i regional'noy ekonomiki [Trends in the development of the market for tourist and recreational services are potentially applicable in the Black Sea region]. Black sea economic studies, no. 32, pp. 111-115.

7. Catalan Tourist Board. Available at: http://act.gencat.cat (accessed 18 June 2021).

8. Cataluña apuesta por el turismo accesible. Available at: https://cronicaglobal.elespanol.com/ vida/catalunaHturismoHaccesible_158339_102.html (accessed 16 June 2021).

9. Easy Walking Tour Gòtic. Available at: https://bcnshop.barcelonaturisme.com/shopv3/en/prod-
uct/23941/easyHwalkingHtourHgotic.html (accessed 18 June 2021).

10. Top 10 tips on inclusive tourism. Available at: https://www.visitbritain.org/sites/default/files/vbHcorporate/top_10_tips_inclusive_tourism.pdf (accessed 18 June 2021$)$.

11. Burkinsky B.V., Osipov V.M., Molina A.V., Goryachuk V.F., Pivovarchuk I.D. (2010) Sotsial'no-ekonomicheskoye razvitiye regionov Chernomorskogo regiona Ukrainy: teoriya, metodologiya, praktika [Socio-economic development of the regions of the Ukrainian Black Sea region: theory, methodology, practice]. Institute of probl. market and ekon.-ekol. issled. NAS of Ukraine. (in Ukrainian)

12. Tourism for All. Available at: https://www.tourismforall.co.uk (accessed 16 June 2021).

13. Turismo accesible. Available at: http://act.gencat.cat/ 408/turismoHaccesible/?lang=es (accessed 16 June 2021). 